\title{
The Effects of Inventory Management Capability on Performance of the Firm- Business Strategies as a Mediating Role
}

\author{
Md. Sazzadur Rahman Khan PhD \\ Assistant Professor \\ Department of Business Administration \\ Stamford University Bangladesh, Bangladesh \\ E-mail: tipuO6bd@yahoo.com
}

Received: April 29, 2020

Accepted: May 30, 2020

Online Published: July 02, 2020

doi: I0.4628I/asfbr.v4i2.649

URL: https://doi.org/I0.4628I/asfbr.v4i2.649

\begin{abstract}
The research aim is to evaluate the mediating aspects of business strategies e.g. differentiation and cost leadership strategy in affecting the aspects of inventory capability e.g. cost-related factors of inventory and techniques of inventory and firm performance e.g. return on asset (ROA) and improve productivity (IMP) of the Bangladeshi garment industry. A survey was utilized to collect information and the questionnaire was dispersed among 385 senior managers in the readymade garment industry of Bangladesh. For the data analysis, AMOS version 24 and SPSS version 23 were used. The findings of the analyzed data revealed that strategies of the business mediate the consequence of inventory materials capability and performance of the firm. The (SEM) results identify that the study model has an appropriate observation fits.
\end{abstract}

Keywords: Inventory Capability, Business Strategy, Firm Performance.

\section{Introduction}

The economy of Bangladesh is heavily dependent on the readymade garment industry which is the foundation for creating job opportunities in the country. In a developing country like Bangladesh, the garment industry is the major driver for industrialization. The readymade garment industry is the basis of foreign earnings and accounted for $81 \%$ of total export income in Bangladesh (BGMEA, 2016). Bangladesh export garment products about $\$ 28$ billion, on the other hand, China who secured the first position in export equivalent to $\$ 130$ billion of readymade garment product (BGMEA, 20I6). The present issue is how China secured this achievement - the answer might be a business strategy with proper inventory management practices. Knitwear sector contribution increases in which the local suppliers provide about $80 \%$ of raw materials and the manufacturers whereas only I5\% of raw materials are supplied by the local suppliers in the case of the woven sector. In the woven sector remaining $85 \%$ raw materials required to import from other nations (Nuruzzaman, 2013). In Bangladesh, there is insufficient raw material production which influences buying fabrics from different countries. It encourages the deficiency of vertical integration. At the end of the day, it creates high lead time to complete the order (Alam \& Natsuda, 2016). There is deficiency also in the greater position of infrastructure that creates in the delay of shipment (Saxena \& Salze-Lozac'h, 2010). This research applies the Resource-Based View (RBV) theory developed by Barney (I99I) to evaluate business strategies as a mediating role in the consequence of inventory materials capability and firm performance of the readymade garment industry.

\section{Literature Review}

Inventory can be defined as a stock that required producing a product e.g. items in work in process and raw materials and supportive activities' e.g. repair, operating, and maintenance Dey and Sumon (20I I). According to Bozarth, Handfield, and Chandiran (2008) there are two categories of safety stock and the cycle of inventory stock. The stock of safety refers to the additional stock to meet up some uncertain demands and stock of cycle is the company's regular used stock Dey and Sumon (20II). According to Farahani and Rezapour (20II), stocks are reserved for various reasons- to reduce uncertainties, further 
sale to others, co-ordinate manufacturing process, and to achieve economies in respect of objectives. Inventory material management consists of planning, storing, and processing materials in the right place, right quantity, right quality, and the right time.

In Malaysia, inventory capability was focused on the garment industry by Bin Syed, Mohamad, Rahman, and Suhaimi (2016). The purpose of the inventory management capability of this research was to evaluate the association between inventory management and company performance. Arrangements between the evaluation of the company's performance and inventory management were identified based on days on inventory and). Days on inventory referred to identify the number of days it would be required to convert turnover from the inventory. High inventory piled up for the long term is not favorable for the company which is the major factor for business failure. Return on assets (ROA) can be defined as net profit generated after the tax has been paid divided by the company's total assets. Results indicated a direct connection between increased values on assets (ROA) and days on inventory.

It was examined the connotation between inventory capability and firm performance covering the period of I9922002 by Roumiantsev and Netessine (2005). In this study, traditional variables e.g. lead time margins and inventory levels were used and found there was no connection between the reduced level of inventory and greater enactment of assessment in terms of increased values on assets (ROA). Shin, Ennis, and Spurlin (2015) evaluated the affiliation between firm performance and inventory capability which reveals that a lower margin of inventory acquires a higher profit. Koumanakos (2008) evaluated the inventory management effects on the firm performance grounded on varieties of industrial sectors namely textile, food, and chemicals representing the period of 2000- 2002 in Greece. The purpose was to evaluate the connection between inventory management capability and firm performance. The study focused on the traditional measurement e.g. levels of inventory, lead time, and demand. The analysis also revealed that the firm maintains a high level of inventory that leads to a lower rate of return.

Kimaiyo and Ochiri (2014) stated management of inventory refers to systems about monitoring the inventory, reduction of cost, lead time, and demand of suppliers affect the firm performance. The study also focused that stock holding and cost of the order will improve the performance, inventory management systems reduce cost and in turn generate more profit. Shardeo (2015) examined the special consequences of inventory competency on the performance of the garment industry. It was revealed the positive association between firm competency and inventory turnover. It was also examined various factors that are important to know the concept of inventory management e.g. costs about inventory, costing methods of inventory, models of inventory, and controlling tools for inventory. Costs about inventory entail ordering cost, purchase cost, carrying cost, and shortage cost. Methods of inventory involve current price and standard price, weighted average, first-in-first-out (FIFO), and last-in-fast-out (LIFO). The model of the inventory consists of the economic order quantity (EOQ), inventory controls related to activity-based costing analysis, maximum level, minimum level and reorder level of inventory. Muiruri and Mwangangi (2017) studied to show the effects of material management, warehousing activities with managing inventory. Analysis disclosed that inventory has a great influence on firm performance in respect to material management and warehousing activities.

Various factors associated with inventory management capability namely cost-related factors, techniques of costing about inventory, methods of controlling the inventory, and various methods of inventory. Cost related inventory factors include ordering cost, carrying cost, purchase, and stock out cost. Techniques of costing about inventory include FIFO, Weighted average, LIFO, and standard costing. Models of inventory include EOQ (Economic order quantity). For controlling inventory, various methods like activity-based costing, minimum level, reorder level, maximum level, just in time, and outsourcing have significant effects on firm performance (Shardeo, 2015).

For effectively controlling inventory management, information technology plays a key role to efficiently manage the inventory system. Studies reveal that capacity and demand-oriented factors have a strong influence on inventory management. Demands of buyers always searching for quality of the product, flexibility, and delivery of the product. Safety stock levels are affected by their regular demand for inventory management. The disparity of capacity adversely affected inventory management. Sudden demand causes an increase or decrease in inventory level (Basaran, 2013).

$\mathrm{H}_{\mathrm{I}}$ : Business strategies have mediating effects of cost associated aspects of inventory on firm performance- ROA

$\mathrm{H}_{2}$ : Business strategies have mediating effects of cost associated aspects of inventory on firm performance- IMP

$\mathrm{H}_{3}$ : Techniques of inventory and firm performance- $\mathrm{ROA}$ are mediated by business strategies

$\mathrm{H}_{4}$ : Techniques of inventory and firm performance-IMP are mediated by business strategies 


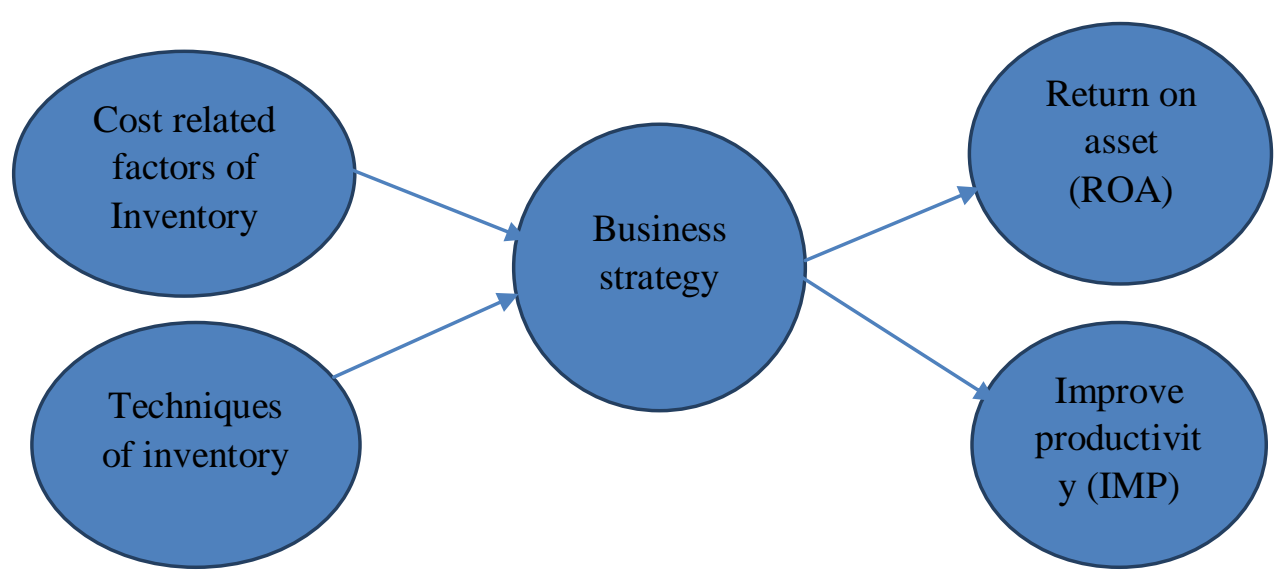

Figure I. Illustrates the conceptual framework

\section{The Methodology of the Study}

The structure developed in this study is specified in figure one. As elucidated previously, this structure consists five constructs: 'cost-related factors of inventory, and 'techniques of inventory', are treated as independent paradigms, 'business strategy' is considered as an intermediating paradigm, and 'return on asset (ROA)' and 'improve productivity (IMP)'are dependent constructs.

\section{I Research Instrument}

To collect data in this study, a questionnaire was served that comprises 39 questions dividing into separate elements. The preliminary portion contains I8queries of the respondents. It contains demographic information. The other portion contains 2I queries which are constructed based on Likert scales (Five points). These scales are developed based on distinguished authors Namusonge, Mukulu, and Iravo (2017), Bin Syed et al. (2016), De Sousa Batista, de Oliveira Lisboa, Augusto, and de Almeida (2016), Rakovska (2013), Lynch, Keller, and Ozment (2000), Zahra and Covin (1993).

\subsection{Data Collection}

The respondents in the questionnaires were experienced managers in 2018 from the upper export readymade garment in Bangladesh. The questionnaires circulated among 450 people. 385 respondents out of 450 were correctly accomplished and were properly used.

\subsection{Reliability, Validity and Measurement Scales}

The value of Cronbach's alpha in this study was satisfactory and it was above 0.70 . The value of Cronbach's alpha in this studyinventory management capability 0.86 , business strategies $0.9 \mathrm{I}$, and firm performance $0.8 \mathrm{I}$. Meanwhile, the questionnaires were developed through borrow/ adjust from specialists.

Table I. Table of measurement

\begin{tabular}{ccccc}
\hline Items and Factors & $\begin{array}{c}\text { Loading } \\
\text { (Estimated) }\end{array}$ & $\begin{array}{c}\text { Loading } \\
\text { (Standardized) }\end{array}$ & $\begin{array}{c}\text { Error of } \\
\text { Standard }\end{array}$ & Critical ratio \\
\hline $\begin{array}{c}\text { Inventory management competency } \\
(\alpha=0.86)\end{array}$ & & & \\
IMC1 & 0.985 & 0.972 & 0.073 & 23.562 \\
IMC2 & 1.000 & 0.850 & - & - \\
IMC3 & 0.940 & 0.841 & 0.051 & 22.974 \\
IMC4 & 0.888 & 0.758 & 0.644 & 21.890 \\
IMC5 & 0.774 & 0.896 & 0.554 & 26.760 \\
$\quad$ & & & \\
\hline Business strategies $(\alpha=0.9 \mathrm{I})$ & & & \\
Cost leadership strategies & &
\end{tabular}




\begin{tabular}{|c|c|c|c|c|}
\hline CLSI & 1.998 & 0.824 & 0.198 & 8.075 \\
\hline CLS2 & I. 258 & 0.700 & 0.167 & 9.765 \\
\hline CLS3 & 1.300 & 0.754 & - & - \\
\hline \multicolumn{5}{|c|}{ Differentiation strategies } \\
\hline DSI & I.234 & 0.543 & 0.103 & 10.032 \\
\hline DS2 & I.I43 & 0.432 & - & - \\
\hline DS3 & 1.334 & 0.323 & 0.143 & 9.633 \\
\hline DS4 & 1.212 & 0.766 & 0.156 & I I.785 \\
\hline DS5 & I.32I & 0.876 & 0.130 & 10.789 \\
\hline \multicolumn{5}{|c|}{ Firm performance $(\alpha=0.8 \mathrm{I})$} \\
\hline ROA & 0.675 & 0.689 & 0.095 & I 8.437 \\
\hline IMP & 0.590 & 0.878 & 0.050 & - \\
\hline
\end{tabular}

\subsection{Inventory Management Capability Scale}

Inventory management capability scale was measured by factors including cost of inventory management, shortages of frequency, inventory control techniques, the efficiency of inventory, long inventory days (Namusonge et al., 2017; Lwiki, Ojera, Mugenda, \& Wachira, 2013).

\subsection{Business Strategies Scale}

Business strategies scale was measured based on cost leadership and differentiation strategies such as cost minimization, procurement efficiency, full capacity utilization, controlling overhead, methods, and tools of quality control number of a new product, rate of new product development (Zahra \& Covin, 1993).

\subsection{Scale of Firm Performance}

Firm performance scale refers to the extent of return on assets that were measured by total income before interest expense divided by total average assets (Zhao, Dröge, \& Stank, 200I). Improve productivity was identified by the percentage of labor productivity-comparing percentage of labor productivity from the year of 2013- 2015 (Prajogo \& Shoal, 2006).

\section{Results}

\section{I Testing Hypothesis}

In this research, for the data analysis, SPSS 23 and AMOS 24 software was used. The questionnaire validity was identified through a load assessment procedure, confirmatory factor analysis, and extracted average variance. In the hypothesis portion and systematic results, Friedman and Spearman test of correlation, structural equation modeling, were engaged. For the testing hypothesis, the maximum alpha error was considered $0.05(\mathrm{P} \geq 0.05)$. The mediation measurement was performed through regressions ensuring-references about Baron and Kenny, (1986). To get proper mediation, the study considered the meaningful coefficients of correlation among three paradigms (Baron \& Kenny, 1986).

Table 2. Coefficients of correlation among ever al paradigms

\begin{tabular}{|c|c|c|c|c|c|c|c|}
\hline & Mean & $\begin{array}{l}\text { Standard } \\
\text { deviation }\end{array}$ & $\begin{array}{l}\text { Cost factors of } \\
\text { inventory }\end{array}$ & $\begin{array}{l}\text { Techniques } \\
\text { inventory }\end{array}$ & of & $\begin{array}{l}\text { Business } \\
\text { strategy }\end{array}$ & $\mathrm{ROA}$ \\
\hline $\begin{array}{c}\text { Cost factors of } \\
\text { inventory }\end{array}$ & 3.60 & 0.703 & & & & & \\
\hline $\begin{array}{c}\text { Techniques of } \\
\text { inventory }\end{array}$ & 3.18 & 0.856 & $0.6 I^{x+2 x}$ & & & & \\
\hline Business strategy & 3.64 & 0.944 & $0.52^{x+2 x}$ & 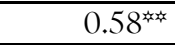 & & & \\
\hline $\mathrm{ROA}$ & 3.53 & I.IO & 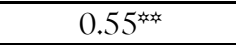 & $0.47^{\text {为社 }}$ & & $0.18^{\text {*⿻ }}$ & \\
\hline IMP & 4.16 & 0.47 & $0.3 I^{x+2 x}$ & 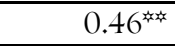 & & 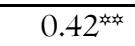 & $0.55^{\text {sax }}$ \\
\hline
\end{tabular}

According to the outputs, cost-related factors of inventory affect strategies of business in the garment industry $(\mathrm{P}<0.0 \mathrm{I})$. However, the results suggest that the structural prototypical strategy of the business has an important consequence on the return on assets of the firm $(\mathrm{P}<0.0 \mathrm{I})$. The standardized coefficient $(\beta)$ effect of cost-related factors on strategies of the business that is equivalent to 0.711 . The standardized coefficient of the effect of modest strategies on return on assets is 
equivalent to I.I4. On the other hand, the standardized coefficient $(\beta)$ of the impact of cost-related factors on improving productivity is equal to 0.17 . All the positive hypothesis relationships are showing in this orientation. Given the results, it can be summarized that the total effect of cost-related factors on firm performance (with the mediating role of business strategies) is significant. Moreover, the standardized coefficient $(\beta)$ of the techniques of inventory on business strategies is equal to 0.232 and the standardized coefficient of the impact of competitive strategies on return on asset is equal to 0.24 . However, the standardized coefficient $(\beta)$ of the impact of techniques of inventory on improve productivity is equal to 0.68 . All the hypothesis relationships in this orientation are also positive. Based on the results, it is summarized that the overall effects of techniques of inventory on firm competency (business strategies as a mediator) are also significant and supported the hypothesis.

Table 3. AMOS output

\begin{tabular}{|c|c|c|c|c|}
\hline $\begin{array}{l}\text { Independent } \\
\text { construct }\end{array}$ & $\begin{array}{l}\text { Mediating } \\
\text { construct }\end{array}$ & Dependent construct & AMOS findings & Result \\
\hline $\begin{array}{l}\text { Cost related } \\
\text { factors of } \\
\text { Inventory }\end{array}$ & Business strategy & Return on asset (ROA) & $\begin{array}{c}\mathrm{S.C}(\beta)=\mathrm{I} . \mathrm{I} 4, \mathrm{p} \text { value }=0.00 \mathrm{I} \text { and } \\
\mathrm{t} \text { value }=4.12 .\end{array}$ & Supported \\
\hline $\begin{array}{l}\text { Cost related } \\
\text { factors of } \\
\text { Inventory }\end{array}$ & Business strategy & $\begin{array}{l}\text { Improve productivity } \\
\text { (IMP) }\end{array}$ & $\begin{array}{c}\mathrm{S} . \mathrm{C}(\boldsymbol{\beta})=0.17, \mathrm{p} \text { value }=0.04 \text { and } \\
\mathrm{t} \text { value }=3.78\end{array}$ & Supported \\
\hline $\begin{array}{l}\text { Techniques of } \\
\text { inventory }\end{array}$ & Business strategy & Return on asset (ROA) & $\begin{array}{c}\mathrm{S} . \mathrm{C}(\beta)=0.24, \mathrm{p} \text { value }=0.00 \mathrm{I} \\
\text { and } \mathrm{t} \text { value }=5.65\end{array}$ & Supported \\
\hline $\begin{array}{l}\text { Techniques of } \\
\text { inventory }\end{array}$ & Business strategy & $\begin{array}{l}\text { Improve productivity } \\
\text { (IMP) }\end{array}$ & $\begin{array}{c}\text { S.C }(\beta)=0.68, p \text { value }=0.03 \text { and } \\
t \text { value }=4.72\end{array}$ & Supported \\
\hline
\end{tabular}

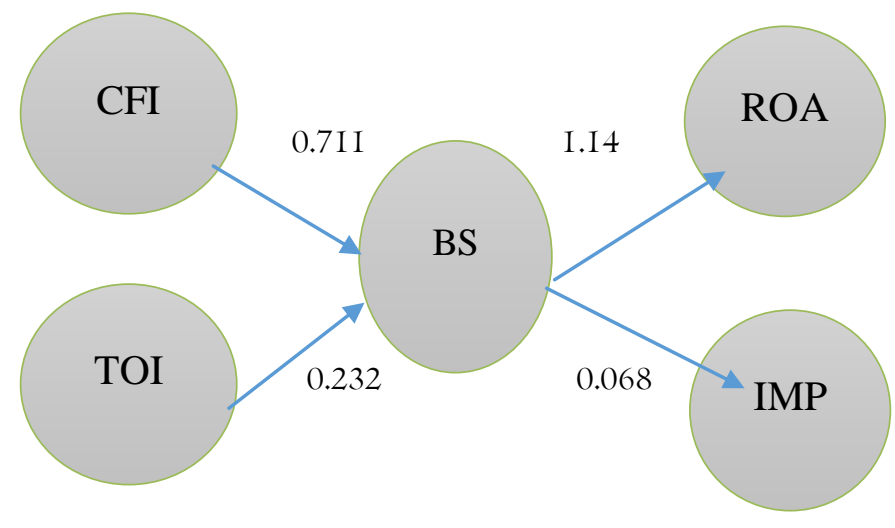

Figure 2. Findings summary

$(\mathrm{RMSEA}=0.088 ; \mathrm{CFI}=0.975 ; \mathrm{TLI}=0.943 ; \mathrm{df}=\mathrm{I} 29 ;$ and Chi-square $=293.15)(\mathrm{p}<0.05)$

\section{Discussion}

The findings revealed that firm performance in readymade garment relies on cost-related factors and various techniques of inventory. The outcomes also propose that these factors and techniques of inventory can affect firm performance through business strategies. All the hypotheses ( $\mathrm{HI}, \mathrm{H} 2, \mathrm{H} 3 \& \mathrm{H} 4)$ identified the positive ( + ve) relationship amongst related factors and techniques of inventory and firm performance $(p \leq 0.05)$. These hypotheses were maintained by preceding research shown by various authors (Bin Syed et al., 2016; Roumiantsev \& Netessine, 2005; Shin et al., 2015; Koumanakos, 2008; Kimaiyo \& Ochiri, 2014; Shardeo, 2015).

As controllable and in organizational factors, they provide firms to establish competitive business strategies required to enhance the organizational effectiveness and efficiency. Although the many competitions in the readymade garment industry, Bangladeshi manufacturers should continuously-proceed phases to advance intra-organizational aspects resulting intensify firm activities progressively. It's necessary to use enterprise resource planning (ERP) for the further development of the production 
process. Garment manufacturers should give effort to have comprehensive control over the production processes and quality of inventory.

From the above findings, numerous contributions have been identified for the theory with the practice of inventory management. At first, logistics can be interlinked with strategic management by developing a new framework with theory. Secondly, present research contributes to the readymade garment industry about the new information for the RBV researches. Thirdly, the analysis engages a model concerning structural equation to test the hypothesis which supports consistency in clarifying the output. Finally, this issue highlights managers dedicating a vigilant deliberation to interior factors that they can maintain to lower the costs that allow the readymade garment factories in Bangladesh to take its place around the international market.

\section{Conclusion}

Inventory management consists capable to forecast and measurability of inventory management practices that reduce cost and provides inventory control efficiency. Inventory is the most significant portion of any business, particularly for the garment industry. It is hidden charges which are to be measured for sustaining in the recent competitive world. Besides costs, improve productivity is also a crucial part of the garment industry. Inventory management also advances the level of productivity to survive in the present world. So, a garment manufacturing firm indispensable to fix the best practices regarding inventory monitoring to expand the return of assets in addition to productivity improvement. Planning inventory is an important part that is to be done effectively and efficiently. Without efficient inventory planning, the firm cannot be reached at the optimum level of inventory management strategy as well as a business strategy.

It's important to discourse that few limitations exist in the present issues. At first, this research attentive in business strategies e.g. cost leadership with differentiation strategies, which does not fulfill the third party logistics strategy. Secondly, the results of current issues were related to readymade garment factories particularly firms engaged with export concerning making, packaging, and cutting systems. Some variables were restricted to some extent in respondents' query e.g. improve productivity, increased value in assets. Finally, due to confidential data, it was gathered based on the experienced manager's observations. One can investigate further negotiation skills and experienced personnel for strategic purchasing. Strategic cost control and firm performance could be further researchable work.

\section{References}

Alam, M. S., \& Natsuda, K. (2016). The competitive factors of the Bangladeshi garment industry in the post-MFA Canadian Journal of Development Studies/Revue canadienned'études du développement, 37(3), 316-336.

Baron, R. M., \& Kenny, D. A. (I986). The moderator-mediator variable distinction in social psychological research: Conceptual, strategic, and statistical considerations. Journal of personality and social psychology, 5I(6), I I73.

Barney, J. (I99I). Firm resources and sustained competitive advantage. Journal of Management, I7(I), 99-I20.

Başaran, B. (2013). Effects of operational and structural conditions on inventory management in large manufacturing enterprises. Istanbul university journal of the school of business administration, 42(I).

Bin Syed, S. J. A. N., Mohamad, N. N. S., Rahman, N. A. A., \& Suhaimi, R. D. S. R. (2016). A study on the relationship between inventory management and company performance: A case study of the textile chain store. Journal of Advanced Management Science, 4(4).

Bozarth, C. C., Handfield, R. B., \& Chandiran, P. (2008). Introduction to operations and supply chain management. Upper Saddle River, NJ: Pearson Prentice Hall.

BGMEA. (20I6). Bangladesh garment manufacturers and exporters association. Retrieved from http://www.bgmea.com.bd/

Dey, P. K., \& Sumon, M. T. H. (20II). Effects of the post-multi-fiber agreement on Bangladesh readymade garments sector. N.P.: LAP-LAMBERT Academic Publishing

De Sousa Batista, P. C., de Oliveira Lisboa, J. V., Augusto, M. G., \& de Almeida, F. E. B. (2016). Effectiveness of business strategies in Brazilian textile industry. Revista de Administração, 5I(2), 225-239.

Farahani, R., \& Rezapour, S. (2011). Logistics operations and management: concepts and models. N.P.: Elsevier.

Kimaiyo, K. K., \& Ochiri, G. (20I4). Role of inventory management on the performance of manufacturing firms in Kenya-A case of new Kenya cooperative creameries. European Journal of Business Management, 2(I), 336-34I.

Koumanakos, D. P. (2008). The effect of inventory management on firm performance. International journal of productivity and performance management, 57(5), 355-369.

Lwiki, T., Ojera, P. B., Mugenda, N. G., \& Wachira, V. K. (2013). The impact of inventory management practices on the financial performance of sugar manufacturing firms in Kenya. International Journal of Business, Humanities, and Technology, 3(5), 75-85.

Lynch, D. F., Keller, S. B., \& Ozment, J. (2000). The effects of logistics capabilities and strategy on firm performance. Journal of business logistics, $2 I(2), 47$. 
Muiruri, K. M., \& Mwangangi, P. (2017). Influence of inventory management of the performance of the energy sector in Kenya: A case of Kenya power limited.

Namusonge, E., Mukulu, E., \& Iravo, M. (2017). Influence of Procurement Capabilities on Firm Performance of Manufacturing Entities in Kenya. International Joumal of Academic Research in Business and Social Sciences, 7(2), 507-520.

Nuruzzaman, M. (2013). Improving the competitiveness of readymade garment (RMG) industry of Bangladesh-Analysis of supply chains (Doctoral dissertation). N.P

Prajogo, D. I., \& Sohal, A. S. (2006). The relationship between organization strategies, total quality management (TQM), and organization performance-the mediating role of TQM. European Journal of Operational Research, I68(I), 35-50.

Rakovska, M. (2013). The impact of strategy and logistics on performance: A methodological framework. Research in Logistics \& Production, 3.

Roumiantsev, S., \& Netessine, S. (2005). Should inventory policy be lean or responsive? Evidence for US public companies.

Saxena, S. B., \& Salze-Lozach, V. (2010). Competitiveness in the garment and textiles industry: Creating a supportive environment: A Case Study of Bangladesh. N.P

Shardeo, V. (2015). Impact of inventory management on the financial performance of the firm. IOSR Journal of Business and Management (IOSR-JBM), OI-I2.

Shin, S., Ennis, K. L., \& Spurlin, W. P. (2015). Effect of inventory management efficiency on profitability: Current evidence from the US manufacturing industry. Journal of Economics and Economic Education Research, I6(I), 98.

Zahra, S. A., \& Covin, J. G. (1993). A business strategy, technology policy, and firm performance. Strategic management journal, I4(6), 45I-478.

Zhao, M., Dröge, C., \& Stank, T. P. (200I). The effects of logistics capabilities on firm performance: customer-focused versus information-focused capabilities. Journal of Business Logistics, 22(2), 91-I07.

\section{Copyrights}

Copyright for this article is retained by the author(s), with first publication rights granted to the journal. This is an open-access article distributed under the terms and conditions of the Creative Commons Attribution license (http://creativecommons.org/licenses/by/4.0/). 